\title{
Оптимизация выделения мтДНК из клубней картофеля с использованием различных сорбционных носителей и разной степени очистки митохондрий
}

\author{
(C) 2020 Ситников В.В. ${ }^{1}$, Гуреев А.П. ${ }^{1,2}$, Виткалова И.Ю. ${ }^{1,2}$, \\ Смирнов А.В. ${ }^{1}$, Попов В.Н. ${ }^{1,2}$ \\ ${ }^{1}$ Воронежский государственный университет, Воронеж \\ ${ }^{2}$ Воронежский государственный университет инженерных технологий, Воронеж
}

Поступила в редакцию 19.11.2020 г.

DOI: $10.17308 /$ sorpchrom.2020.20/3147

В настоящее время существует интерес к оценке повреждений мтДНК как к маркеру окислительного стресса, при этом данный вопрос недостаточно изучен для мтДНК растений. Однако митохондриальный геном растений обладает рядом особенностей, которые могут существенно затруднять проведение ПЦР. При недостаточной очистке митохондрий пробы всё ещё могут быть контаминированы ядерной и пластидной ДНК, что может привести к неспецифичному отжигу праймеров. Целью данной работы является оптимизация процесса выделения мтДНК из картофеля (Solanum tuberosum L.) при использовании различных сорбционных носителей. Применение методов сорбции на твердофазных носителях является наиболее эффективным для крупных по размерам молекул мтДНК. Нами было проведено сравнение эффективности трёх коммерческих наборов для выделения ДНК: diaGene (Диа-М, Россия), Проба-ГС (ДНК-Технология, Россия) и Plasmid miniPrep (Evrogen, Poссия). Эти методы подразумевают связывание ДНК с поверхностью сорбционных колонок (diaGene, Plasmid miniPrep), либо на силикатном сорбенте (Проба-ГС). Для оценки эффективности рассмотренных методов с помощью количественной ПЦР был измерен уровень обогащения мтДНК. Также приведено сравнение эффективности выделения ДНК при разных степенях очистки исходного материала - при использовании гомогената картофеля, при очистке дифференциальным и центрифугированием в градиенте Перколла. Низкий уровень насыщенности мтДНК наблюдался при выделении из гомогената, высокий - при выделении митохондрий градиентным центрифугированием. При использовании градиентного центрифугирования высокий уровень обогащения мтДНК наблюдался только при выделении ДНК набором Проба-ГС. Нами было обнаружено, что наибольшим насыщение материала мтДНК будет при использовании набора Plasmid miniPrep при предварительной очистке митохондрий градиентным центрифугированием. Только градиентное центрифугирование способно максимально очистить митохондрии от примесей. Использование набора Plasmid miniPrep, предназначенного для выделения плазмидной ДНК, показывает свою эффективность и для мтДНК, которые аналогично пластидным ДНК являются преимущественно кольцевыми. В результате удалось разработать оптимизированный процесс выделения мтДНК картофеля, пригодного для проведения дальнейших молекулярно-генетических исследований. Этот метод может быть использован для любых научных изысканий, связанных с изучением митохондриального генома растений.

Ключевые слова: растительная мтДНК, Solanum tuberosum, выделение ДНК, митохондрии

\section{Введение}

Одним из основных маркеров окислительного стресса является повреждение митохондриальной ДНК. Количественное измерение этого показателя имеет большое значение при моделировании различных патологических процессов в клетке [1]. В свою очередь митохондрион основных модельных животных таких как: мышь, 
крыса, человек гораздо лучше изучен, нежели митохондрион растений. Митохондриальный геном животных достаточно хорошо картирован, описан и аннотирован, также известны участки, дублирующиеся в ядерном геноме, которые всегда необходимо учитывать при подборе праймеров [2]. Иная ситуация наблюдается для митохндриального генома растений. Отличительной чертой которого служит размер. Так же строение генома отличается от вида к виду, что в свою очередь приводит к увеличению количества и разнообразия функций. Однако, в отличии от животного генома, геном растений описан фрагментарно [3].

К тому же, на сегодняшний день нельзя найти исчерпывающих моделей повреждения митохондриального генома при окислительном стрессе. Совокупность данных факторов создаёт предпосылки дальнейшего всестороннего изучения митохондриального генома растительной клетки.

В виду недостаточности изучения митохондриона растений, не всегда можно с точностью судить о наличии или отсутствии в исследуемом материале псевдогенных участков. Для того, чтобы избежать подобных затруднений, необходимо разработать наиболее оптимальную модель выделения мтДНК.

Существуют различные методы выделения ДНК, такие как выделение ДНК в жидкой среде (фенол-хлороформный метод, метод со СТАВ-буфером), сорбция на твёрдых поверхностях (колоночные методы выделения, использование силикатного сорбента), очистка ДНК с помощью магнитных частиц и некоторые другие. Сорбционные методы выделения ДНК являются достаточно эффективными в особенности для крупных по размерам молекул ДНК $[4,5]$. При оптимизированном процессе выделения чистой мтДНК, значительно снижается вероятность неспецифичного отжига праймеров в ходе проведения ПЦР, связанного с наличием псевдогенных участков.

Целью данного исследования является оптимизация процесса выделения мтДНК из картофеля (Solanum tuberosum L.) при использовании трёх различных коммерческих наборов для выделения ДНК, основанных на сорбционных процессах. Исследование проводилось с использованием разного вида исходного материала: гомогената картофеля, митохондрий, полученных дифференциальным центрифугированием и митохондрий, полученных градиентным центрифугированием с использованием Перколла.

\section{Экспериментальная часть}

В эксперименте были использованы три степени очистки исходного материала для выделения митохондрий, включавших в себя гомогенизирование, дифференциальное и градиентное центрифугирование (рис. 1). Гомогенизирование картофеля проводилось с использованием среды для выделения митохондрий. Выделение ДНК осуществлялось наборами dia-Gene (Диа-M, Россия), Проба-ГС (ДНК-Технология, Россия), Plasmid miniPrep (Evrogen, Россия). Для первой группы выделение ДНК осуществлялось непосредственно после гомогенизирования.

Среда для выделения митохондрий. 100 мМ маннитола, 225 мМ сахарозы, 1 мМ ЭДТА, 200 мМ Hepes, 1 mM DTT, 1.5 г/дм³ BSA, pH среды 7.4.

Выделение митохондрий методом дифференциального центрифугирования. Гомогенат дважды последовательно центрифугировали на охлаждаемой центрифуге Hermle Z 383 K (Hermle, Германия) в течение 5 минут при 1500 g и 4000 g с последующим удалением осадка, затем центрифугировали при $15000 \mathrm{~g}$ в течение 15 минут с последующим удалением супернатанта. Затем повторно центрифугировали без охлаждения при 15000 g в течение 15 минут. Полученный осадок ресуспендировали и использовали для выделения ДНК. 
1.

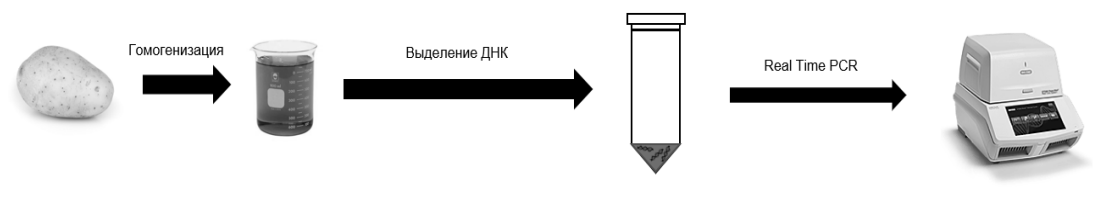

2.

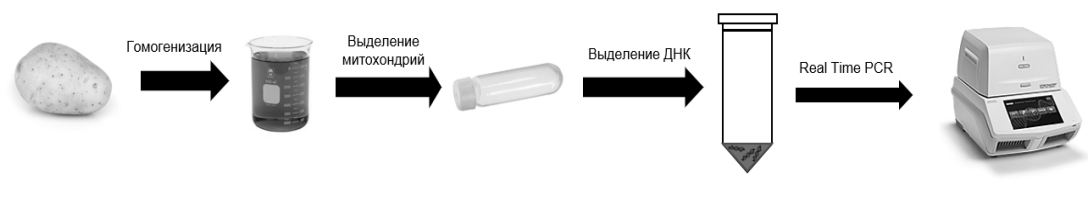

3.

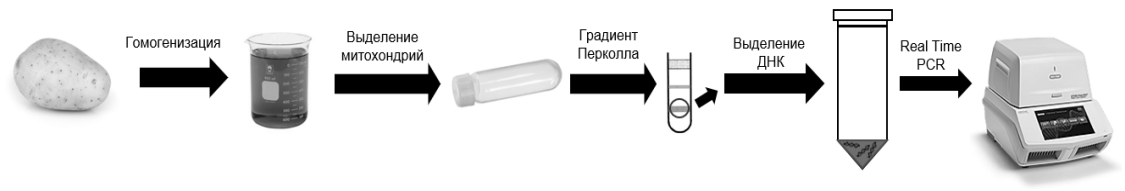

Рис. 1. Схема проведения эксперимента

Fig. 1. Scheme of the experiment

Выделение митохондрий методом градиентного центрифугирования. Гомогенат картофеля дважды последовательно центрифугировали на охлаждаемой центрифуге при $1500 \mathrm{~g}$ и $4000 \mathrm{~g}$ в течение 5 минут, удаляли осадок, после чего центрифугировали при $15000 \mathrm{~g}$ в течение 15 минут, супернатант удаляли. Полученный осадок ресуспендировали и наносили на $17 \%$-ный раствор Перколла с последующим центрифугированием в охлаждаемой центрифуге при $30000 \mathrm{~g}$ в течение 30 минут. Из полученного раствора отбирали фракцию митохондрий и доводили средой, после чего центрифугировали при $18000 \mathrm{~g}$ в течение 15 минут. Полученный осадок центрифугировали без охлаждения при $16000 \mathrm{~g}$ в течение 10 минут. Осадок ресуспендировали и использовали для выделения ДНК.

Выделение ДНК набором diaGene (Диа-М, Россия). К ресуспендированному осадку прибавляли 200 мкл «Раствора для сорбции», перемешивали на вортексе и центрифугировали 1 минуту при 13000 об/мин. Супернатант вносили в сорбционную колонку вместе с 200 мкл «Раствора для промывки $1 »$, центрифугировали 1 минуту при 13000 об/мин, удалили фильтрат. Затем внесли 300 мкл «Раствора для промывки 1», центрифугировали 1 минуту при 13000 об/мин, удаляли фильтрат. После этого в сорбционную колонку добавляли 500 мкл «Раствора для промывки 2», центрифугировали при 13000 об/мин одну минуту. Далее этот этап повторяли. Затем центрифугировали колонку ещё раз при 13000 об/мин в течение 30 секунд для удаления остатков раствора. После этого ДНК элюировали внесением в сорбционную колонку 30 мкл деионизированной воды, инкубировали одну минуту. Затем центрифугировали 1 минуту при 13000 об/мин, осаждая в пробирке ДНК.

Выделение ДНК набором Проба-ГС (ДНК-Технология, Россия). В пробирку с ресуспендированным осадком добавляли 150 «Лизирующего раствора» и 20 мкл ресуспендированного сорбента, после чего перемешивали на вортексе. Полученную смесь термостатировали 20 минут при $50^{\circ} \mathrm{C}$, после чего центрифугировали при $16000 \mathrm{~g}$ в течение одной минуты. Супернатант удаляли, к сорбенту добавляли 200 мкл «Раствора для промывки 1», смесь перемешивали на вортексе, после чего центрифугировали при 16000 g одну минуту. Аналогичные этапы проводили с «Раствором для промывки 2» и «Раствором для промывки 3». Затем, после удаления супернатанта, осадок в открытой пробирке высушивали термостатированием при $50^{\circ} \mathrm{C}$ в течение 5 минут. К осадку прибавляли 100 мкл элюирующего раствора, перемешивали на вортексе, затем прогревали на термостате в течение 5 минут при $50^{\circ} \mathrm{C}$. Смесь

Ситников и др. / Сорбционные и хроматографические процессы. 2020. Т. 20. № 6. С. 789-796 
центрифугировали при 16000 g одну минуту, отбирали супернатант с элюированной ДНК.

Выделение ДНК набором Plasmid miniPrep (Evrogen, Россия). К ресуспендированному осадку добавляли 250 мкл «Лизирующего раствора», после чего содержимое пробирки осторожно перемешивали вручную, затем инкубировали 1 минуту при комнатной температуре. Далее вносили 350 мкл «Нейтрализующего раствора», полученную смесь также осторожно вручную перемешивали и инкубировали 1 минуту при комнатной температуре, после чего центрифугировали 10 минут при 13000 g. Осветлённый супернатант переносили в спин-колонку, помещённую в собирательную пробирку, затем центрифугировали 30 секунд при 10000 g. Фильтрат из собирательной пробирки удаляли, вносили 700 мкл «Промывочного раствора», центрифугировали 30 секунд при $10000 \mathrm{~g}$, затем колонку центрифугировали повторно для удаления остатков промывочного раствора, удаляли фильтрат. Колонку помещали в новую пробирку $\left(1.5 \mathrm{~cm}^{3}\right)$, оставляли на 5 минут при комнатной температуре для удаления остатков спирта. Затем в центр мембраны колонки наносили 50 мкл «Элюирующего раствора», инкубировали 1 минуту при комнатной температуре. Выделенную ДНК осаждали центрифугированием при 10000 g в течение 30 секунд.

Проведение ПЦР в реальном времени. Для оценки обогащённости материала мтДНК использовался метод Real-Time PCR на термоциклере CFX96 Touch (Bio$\mathrm{Rad}, \mathrm{CША).} \mathrm{Протокол} \mathrm{ПЦР} \mathrm{реакции:} \mathrm{предварительная} \mathrm{денатурация} \mathrm{-} 3$ минуты, $95^{\circ} \mathrm{C}$; денатурация $-95^{\circ} \mathrm{C}, 10$ секунд; отжиг $-59^{\circ} \mathrm{C}, 30$ секунд; элонгация $-72^{\circ} \mathrm{C}$, 30 секунд; 40 циклов. Реакционная смесь для ПЦР на одну пробу включала 14 мкл деионизированной воды, 4 мкл смеси qPCRmix-HS SYBR, 1 мкл смеси прямого и обратного праймера и 1 мкл ДНК. Были использованы две пары праймеров 26s rRNA в качестве таргетного гена и stNuclear в качестве референсного. Количественный анализ проводился по формуле $2^{(-\Delta \Delta \mathrm{Ct})}$. Перечень праймеров приведен в таблице.

Таблица. Перечень использованных праймеров

Table. List of primers used

\begin{tabular}{|c|c|}
\hline Праймер & Последовательность 5' -3, \\
\hline STNucl_F & GAACCATGGCATTGTGTCACT \\
\hline STNucl_R & TCATGACAAGTGTAGGGGGT \\
\hline ST26sFSh & CATCCGCCCCAGATAAACTA \\
\hline ST26sRSh & ATAGGTGGGAGGTGGTGACA \\
\hline
\end{tabular}

Электрофорез ПЦР-продукта. Для проведения электрофореза готовили $0.6 \%$ агарозный гель, для этого 600 мг агарозы растворяли в 30 мл воды, затем добавляли 600 мкл ТАЕ-буфера. Полученный раствор кипятили вплоть до образования прозрачной гомогенной смеси. В остывший раствор добавляли 3 мкл бромистого этидия, затем заливали в форму до застывания геля. Далее гель помещали в камеру для электрофореза, наполненную $1 \mathrm{X}$ TAЕ-буфером, в первую и последнюю лунки вносили 8 мкл маркера длин ДНК, в остальные лунки вносили по 6 мкл ДНК и 2 мкл 4X Gel Loading Dye (Evrogen, Россия). Для проведения электрофореза использовали источник питания «Эльф-4» (ДНК-Технология, Россия). Протокол проведения электрофореза: 40 минут, 150 мА, 100 В, 20 Вт. По окончании процесса результат фиксировали при помощи системы для гель-документирования Bio-Rad Gel Doc XR+ (BioRad, США).

Статистическая обработка. Статистический анализ проводился с использованием программного обеспечения Microsoft Excel 2016 (Microsoft, США). Данные 
представлены в виде значений среднего арифметического \pm значение стандартной ошибки. Проверку нормальности распределения провели с использованием критерия согласия Колмогорова. Экспериментальные данные соответствовали нормальному распределению, различия между группами оценивались при использовании t-критерия Стьюдента.

\section{Обсуждение результатов}

Оценку степени обогащения материала мтДНК производили посредством проведения ПЦР в реальном времени, в ходе которой амлифицировались фрагменты ядерной и мтДНК (рис. 2). Размеры ПЦР продукта соответствуют ожидаемым и составляют 20 пн для фрагмента мтДНК и 21 пн для фрагмента ядерной ДНК.

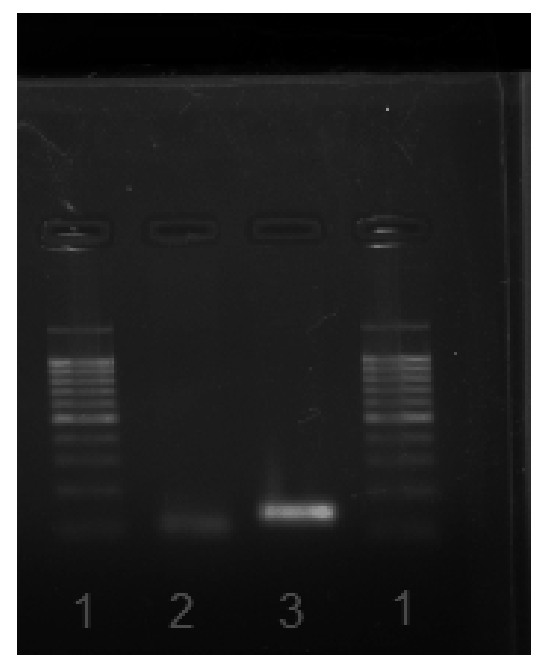

Рис. 2. Электрофореграмма ПЦР-продукта; 1 - ДНК-лестница,

2 - ПЦР-продукт фрагмента ядерной ДНК, 3 - ПЦР-продукт фрагмента мтДНК

Fig. 2. Electrophoregram of the PCR product; 1 - DNA ladder, 2 - PCR-product of the nuclear DNA fragment, 3 - PCR-product of the mtDNA fragment

Было показано, что в группе, где мтДНК выделялась из гомогената, уровень обогащения был одинаково низким для всех образцов независимо от типа используемого сорбента, это может быть связано с тем, что для гомогената характерен высокий уровень контаминации геномной ДНК и другими клеточными компонентами (рис. 3). При выделении мтДНК из митохондрий, предварительно выделенных методом дифференциального центрифугирования, обогащение препарата было выше на $78 \%(\mathrm{p}<0.05)$ (набор Plasmid miniPrep) и в 2.6 раза $(\mathrm{p}<0.05)$ выше при выделении набором Проба-ГС. Такой высокий уровень насыщенности мтДНК при выделении набором Проба-ГС можно предположительно объяснить тем, что в отличие от колоночных методов, в Пробе-ГС используется силикатный сорбент, который вносят непосредственно в среду с ДНК [6].

Более высокий уровень обогащения мтДНК был отмечен для всех наборов при использовании градиентного центрифугирования. Использование данного метода будет значительно более эффективным для выделения митохондрий растений, поскольку при дифференциальном центрифугировании невозможно получить достаточно чистую фракцию митохондрий, что весьма критично в условиях выделения мтДНК $[7,8]$. Для того, чтобы эффективно проводить ПЦР-анализ, проба должна быть максимально насыщена мтДНК, а при использовании дифференциального центрифугирования имеет место контаминация проб пластидной ДНК [7], что несомненно сказывается на результатах анализа.

Ситников и др. / Сорбционные и хроматографические процессы. 2020. Т. 20. № 6. С. 789-796 


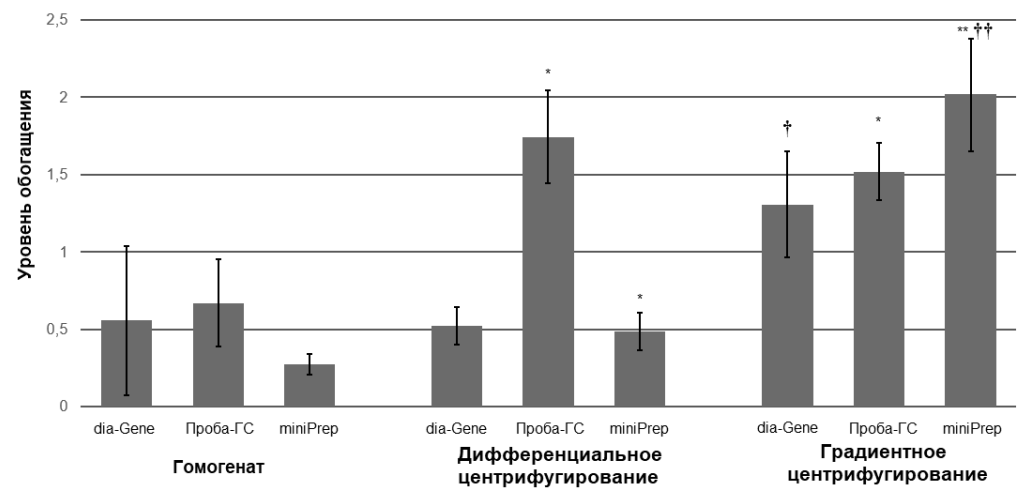

Рис. 3. Обогащение препарата митохондриальной ДНК при использовании различных методов выделения ДНК. $\left(^{*}\right)-\mathrm{p}<0.05,(* *)-\mathrm{p}<0.01$ относительно ДНК, выделенных из гомогената; $(\dagger)-\mathrm{p}<0.05$, $(\dagger \dagger)-\mathrm{p}<0.01$ относительно ДНК, выделенных из митохондрий дифференциальным центрифугированием

Fig. 3. Saturation of the preparation of mitochondrial DNA using various methods of DNA isolation. $(*)-\mathrm{p}<0.05,(* *)-\mathrm{p}<0.01$ relative to DNA isolated from the homogenate; $(\dagger)-\mathrm{p}<0.05,(\dagger \dagger)-\mathrm{p}<0.01$ relative to DNA isolated from mitochondria by differential centrifugation

При использовании для выделения мтДНК набора dia-Gene обогащение препарата возрастает в 2.33 раза по сравнению с аналогичным при выделении мтДНК из гомогената и в 2.5 раза $(\mathrm{p}<0.05)$ при выделении из митохондрий дифференциального центрифугирования. При выделении набором Проба-ГС степень обогащения составляет 2.26 раза $(\mathrm{p}<0.05)$ по сравнению с группой гомогената, но и при этом не имеет значительных различий по сравнению с методом дифференциального центрифугирования. При использовании набора Plasmid miniPrep насыщение препарата мтДНК возрастает в 7.4 раза $(\mathrm{p}<0.01)$ по сравнению с использованием этого же набора при выделении мтДНК из гомогената и в 4.14 раз $(\mathrm{p}<0.01)$ выше по сравнению с группой дифференциального центрифугирования.

Среди наборов, использованных при градиентном центрифугировании, наибольший уровень обогащения мтДНК зафиксирован при выделении набором Plasmid miniPrep, где уровень обогащения выше на $54.48 \%$ в сравнении с набором diaGene и на $32.95 \%$ выше в сравнении с набором Проба-ГС.

Особенностью использования набора Plasmid miniPrep является то, что copбент в данном наборе предназначен для выделения плазмидной ДНК, однако, в работе K.W. Quispe-Tintaya et al. (2013) набор для выделения плазмидной ДНК используется и для выделения ДНК митохондрий [9]. Это можно объяснить структурным сходством данных молекул, зачастую являющихся кольцевыми $[10,11]$, что в значительной мере обуславливает то, что фильтрующая поверхность данных сорбционных колонок будет обладать большим сродством к кольцевым молекулам ДНК, нежели аналогичная поверхность в колонках других наборов. При этом необходимо учитывать тот факт, что растительные мтДНК разных видов могут значительно различаться и быть представлены разным набором больших и малых кольцевых и линейных молекул, а также коротких молекул различных форм [10]. Митохондрион картофеля представлен тремя кольцевыми молекулами разных размеров [12], в связи с чем данный метод выделения ДНК может проявлять свою высокую эффективность. Однако стоит учитывать, что для выделения мтДНК из других растений, где часть митохон- 
дриона представлена другими формами цепи ДНК, возможно, будут оптимальны другие сорбционные носители для выделения.

\title{
Заключение
}

В ходе исследования нами было показано, что по степени насыщенности материала мтДНК методы значительно различаются как между собой, так и в зависимости от подготовки исходного материала. Было установлено, что для выделения мтДНК из картофеля наиболее оптимальным является использование набора Plasmid miniPrep c проведением предварительного градиентного центрифугирования. При применении градиентного центрифугирования значительно снижается число посторонних клеточных компонентов, а материал для выделения ДНК максимально насыщен митохондриями. Использование набора Plasmid miniPrep наиболее эффективно по сравнению с другими методами в силу того, что сорбционные колонки данного набора могут обладать большим сродством к кольцевым молекулам, в силу чего способны сорбировать не только плазмидные ДНК, но и ДНК митохондрий.

Исследование выполнено при финансовой поддержке Российского Научного Фонда в рамках научного проекта № 20-14-00262.

\section{Список литературы/References}

1. Malik A.N., Czajka A., Mitochondrion, 2013, Vol. 13, No 5, pp. 481-492.

2. Gureev A.P., Shaforostova E.A., Starkov A.A., Popov V.N., Toxicology, 2017, Vol. 382, pp. 67-74.

3. Sloan D.B., New Phytol., 2013, Vol. 200, No 4, pp. 978-985.

4. Corcoll N., Osterlund T., Sinclair L., Eiler A., FEMS Microbiol Lett., 2017, Vol. 364, No 14.

5. Ahmed Z., Fu Y.B., Plant Methods, 2015, No 11, pp. 56.

6. Boom R., Sol C.J., Salimans M.M., Jansen C.L., J Clin Microbiol., 1990, Vol. 28, No 3, pp. 495-503.
7. Klein M., Binder S., Brennicke A., Methods Mol Biol., 1998, Vol. 82, pp. 49-53.

8. Douce R., Bourguignon J., Broquisse R., Neubureger M., 1987, Methods In Enzymology, Vol. 148, pp. 403-415.

9. Quispe-Tintaya K.W., White R.R., Popov V.N., Vijg J., Biotechinques, 2013, Vol. 55, No 3, pp. 133-136.

10.Gualberto J.M., Mileshina D., Wallet C., Niazi A.K., Biochimie., 2014, Vol. 100, pp. 107-120.

11.Higgins N.P., Vologodskii A.V., Microbiol Spectr., 2015, Vol. 3, No 2, pp. 1128.

12.Varre J.S., D'Agostino N., Touzet P., Gallina S., Int J Mol Sci., 2019, Vol. 20, No 19, pp. 4788.

\section{Optimization of mtDNA purification from potato tu- bers using various sorption carriers and different de- grees of mitochondria isolation}

\author{
(C) 2020 Sitnikov V.V. ${ }^{1}$, Gureev A.P. ${ }^{1,2}$, Vitkalova I.Yu. ${ }^{1,2}$, \\ Smirnov A.V. ${ }^{1}$, Popov V.N. ${ }^{1,2}$ \\ ${ }^{1}$ Voronezh State University, Voronezh \\ ${ }^{2}$ Voronezh State University of Engineering Technologies
}

Currently, there is interest in assessing mtDNA damage as a marker of oxidative stress, and this issue is not sufficiently studied for plant mtDNA. However, the mitochondrial genome of plants has a number of features that can significantly complicate PCR. With insufficient purification of mitochondria, samples can still be contaminated with nuclear and plastid DNA, which can lead to non-specific annealing of primers. The 
aim of this work is to optimize the process of mtDNA isolation from potatoes (Solanum tuberosum L.) using various sorption media. The use of sorption methods on solid-phase carriers is most effective for large-sized mtDNA molecules. We compared the effectiveness of three commercial DNA isolation kits: diaGene (DiaM, Russia), Proba-GS (DNA Technology, Russia) and Plasmid miniPrep (Evrogen, Russia). These methods involve binding DNA to the surface of sorption columns (diaGene, Plasmid miniPrep), or on a silicate sorbent (Proba-GS). To assess the effectiveness of the considered methods, the level of mtDNA saturation was measured using quantitative PCR. A comparison of the efficiency of DNA extraction at different degrees of purification of the initial material is also given - when using potato homogenate, when cleaning by differential and centrifugation in the Percoll gradient. A low level of mtDNA saturation was observed when isolated from the homogenate, and a high level was observed when mitochondria were isolated by gradient centrifugation. When using gradient centrifugation, a high level of mtDNA saturation was observed only when DNA was isolated by a set of Proba-GS. We found that the greatest saturation of the mtDNA material will be when using the Plasmid miniPrep kit during pre-purification of mitochondria by gradient centrifugation. Only gradient centrifugation can maximally purify the mitochondria from impurities. The use of the Plasmid miniPrep kit, which is designed for the isolation of plasmid DNA, also shows its effectiveness for mtDNA, which is similar to plastid DNA and is predominantly circular. As a result, it was possible to develop an optimized process for isolating potato mtDNA, which is suitable for further molecular genetic studies. This method can be used for any scientific research related to the study of the mitochondrial genome of plants.

Keywords: plant mtDNA, Solanum tuberosum, DNA isolation, mitochondria

Ситников Вадим Вадимович - аспирант кафедры генетики, цитологии и биоинженерии медико-биологического факультета ВГУ, Воронеж

Гуреев Артём Петрович - ассистент кафедры генетики, цитологии и биоинженерии медикобиологического факультета ВГУ, Воронеж; младший научный сотрудники лаборатории метагеномики и пищевых биотехнологий ВГУИТ, Воронеж

Виткалова Инна Юрьевна - аспирант кафедры биохимии и биотехнологии ВГУИТ, Воронеж; младший научный сотрудник кафедры биохимии и физиологии клетки, ВГУ, Воронеж

Смирнов Андрей Владимирович - магистр кафедры генетики, цитологии и биоинженерии медико-биологического факультета ВГУ, Воронеж

Попов Василий Николаевич - д.б.н., професcop, заведующий кафедры генетики, цитологии и биоинженерии медико-биологического факультета ВГУ, Воронеж; ректор ВГУИТ, Воронеж
Sitnikov Vadim V. - Postgraduate student, Department of Genetics, Cytology and Bioengineering, Faculty of Medicine and Biology, VSU, Voronezh; vvs-96@yandex.ru

Gureev Artem P. - Assistant, Department of Genetics, Cytology and Bioengineering, Faculty of Medicine and Biology, VSU, Voronezh; Junior Researcher, Laboratory of Metagenomics and Food Biotechnologies, Voronezh

Vitkalova Inna Yu. - Postgraduate student, Department of Biochemistry and Biotechnology, VSUET, Voronezh; Junior Researcher, Department of Biochemistry and Physiology of the Cell, Voronezh State University, Voronezh

Smirnov Andrey V. - Student, Department of Genetics, Cytology and Bioengineering, Faculty of Medicine and Biology, VSU, Voronezh

Popov Vasily N. - Doctor of Biological Sciences, Professor, Head of the Department of Genetics, Cytology and Bioengineering, Faculty of Medicine and Biology, VSU, Voronezh; Rector of VSUET, Voronezh 